\title{
Achieving the MDG's in Ghana: rhetorics or reality?
}

\author{
J.-E. Gustafsson ${ }^{1}$ \& J. E. Koku ${ }^{2}$ \\ ${ }^{I}$ Department of Land and Water Resources Engineering, KTH, Sweden \\ ${ }^{2}$ Department of Geography and Resources Development, \\ University of Ghana, Ghana
}

\begin{abstract}
The original meaning of the concept sustainability or sustainable development might in an altruistic way have referred to building societies based on a sound environmental practice. This paper shows that the structural adjustments programs (SAP), Poverty Reduction Strategies and the Millennium Development goals (MDG's) compel the Ghanian government to favour economic and fiscal sustainability. This neo-liberal policy has led to increasing inequalities, widening regional disparities, migration from rural areas to quickly grown up peri-urban areas basically within a huge informal sector, and unplanned capital formation and development at large, making claims to achieve the MDG's by 2015 illusory. A way forward for Ghana should be to gradually fence off from the world market and learn from the development efforts of the Kwame Nkrumah first independent government.

Keywords: environmental sustainability, international financial institutions, Ghana, Millennium Development goals, water management.
\end{abstract}

\section{Introduction}

The original meaning of the concept sustainability or sustainable development might in an altruistic way have referred to building societies based on a sound environmental practice. Nowadays the concept has largely been attenuated so it can be attached to almost everything; environmental sustainability, social sustainability, economic sustainability, fiscal sustainability, debt sustainability, sustainable leadership, sustainable trade, sustainable governance etc. This attenuation has the function to conceal the power relations inherited with the concept. 
In September 2000 the Millennium Development Goals (MDG's) to be achieved by 2015 were launched at the United Nation Millennium Summit. Among the well-known eight goals number 1 wishes to "halve, between 19902015 , the proportion of people whose income is less than $\$ 1$ a day" and "who suffer from hunger", number 7 should "ensure environmental sustainability" by the means of "integrate the principles of sustainable development in country policies and programmes...reduce by half the proportion of people without sustainable access to drinking water (later at the Johannesburg 10+ sanitation has been added)... and to achieve significant improvement in lives of at least 100 million slum dwellers, by 2020". Goal number 8 advocates to "develop a Global Partnership for development", which should include commitment to good governance [1].

In this paper we will critically discuss the conditions to implement the MDG's, particularly MDG's number 1, 7 and 8 in their global context, and with Ghana as a country example.

\section{The global context}

In the aftermath of the Thatcherite privatisation programs in the $1980 \mathrm{~s}$ international organizations such as the World Bank, IMF, WTO, OECD, EU etc have pushed for market testing, deregulation and privatisation of public services within a general theoretical frame of neo-liberal solutions. These have been argued to achieve increased efficiency and social developments like poverty eradication. The various privatisation policies are based on the ideological notion that almost all public services and investments are best organized as pure markets [2].

\subsection{The corporate agenda}

The sustainable development concept became a global ideological key-word at the Rio Conference in 1992. The conference was basically prepared by one of the most important industrial lobbyist groups, The Business Council for Sustainable Development, which today gathers more than 170 of the most important internationals. Its chairman was Stephan Schmidheiny, one of the principal owners of the Asea Brown Broveri (ABB) company. He was also in the board of the Néstle and Swatch companies and was a principal shareholder in a Chilian mine, steel and forest company. Together with around 50 other important industrialists they formed the main advisory group to the Rio de Janeiro Earth Summit general secretary Maurice Strong. With Schmidheiny as the main author the group published the book Changing Courses. A Global Business Perspective on Development and Environment [3].

All of its recommendations are based on the belief that only by allowing market forces to operate freely can sustainable development be achieved, as if market forces have a long-term perspective. The representatives for the transnationals claim themselves as the protector of the environment by advocating that trade and investments should not be obstructed by environment 
and import regulations. Instead their advice for impoverished countries was to continue to produce staple commodities for the world market, which should lead to the right price for natural resources, and to co-operate with the transnationals for their new economic order, that in agreement with international financial institutions (IFIs) is labelled "Washington Consensus".

The principal mean for promoting this neo-liberal and environmentimperialistic development would be to favour an attractive investment climate by fulfilling the conditions of macro-economic stability, free and open markets, distinct property rights and political stability. If these conditions were not fulfilled sustainable development was not possible according to the Maurice Strong advisory group. This market policy orientation replaced in developing countries earlier basic needs strategies and dependant theories between the North and South as agents for social change.

This corporate message has been forwarded by the global think-tank World Water Council, the most influential global advisory water institution, which organizes World Water Forums every three years. It had to the world water meeting in Den Haag 2000 worked out a "World Water Vision" as a policy document for the management of world water resources. Comprehensive criticism was addressed from peasant organization, consumer organizations, trade unions etc. These interest groups argued that the World Water Vision depreciated public utility water and sanitation management in favour of private solution all over the globe. The Den Haag meeting has been followed by an intensified discussion between proponents who consider water as a human right, and others who look upon water as an economic good. Later on this contradiction has been reflected at the International Freshwater Conference in Bonn 2001, the Rio+10 meeting in Johannesburg 2002 and the World Water Forums in Kyoto 2003 and Mexico 2006.

\subsection{The failure of fiscal sustainability}

A way of disguising the power aspect is to present the three main concepts of environmental, social and economic sustainability of equal importance [4]. But in practice almost without exception the global and national ruling elite favours economic sustainability or economic growth as the overall goal of development. In developing countries this priority is linked to structural adjustments programs (SAP) advocated since the 1980s by the Bretton Wood institutions (the World Bank and the IMF) and other IFIs as a conditionality for economic assistance and loans giving. But in the beginning of the $21^{\text {st }}$ century critical reviewers recognise that the SAP neo-liberal policy has not delivered the environmental sound and social equitable development stated in the documents and declarations.

The neo-liberal policy under the SAPs emphasizes fiscal discipline, market economy and openness to the global economy. With discredited SAP programs the global international financial institutions needed something else and more appealing to conserve their influence and power. The solution became the MDG's. 
In the international water community it is generally agreed that the MDG's cannot be achieved without a major increase in investments over a sustained period. The International Water and Sanitation Centre (IRC) estimated 2006 the total amount of funding required per year to achieve the MDG's water and sanitation targets within the range of US \$6.5 to US \$75 billion dollars. UNDP Human Development Report 2006 sets this figure at US \$10 billion dollars per year. Stedman writes that the UNDP estimation might seem to be a large sum, but put in a global context it represents less than five days worth of global military spending and less than half what rich countries spend each year on mineral water [5].

It has in the recent years been apparent that the private sector contradictory to what it initially claimed has failed to provide the needed investment. The Report of the Commission of Africa in 2005 concluded that the sharp reduction in infrastructure investments "was a policy mistake founded in the new dogma of the 1980s and 1990s asserting that infrastructure would now be financed by the private sector"[6]. The private sector did not compensate for the drop in public investment as it was hoped says the IMF [7]. Thus the State and therefore public investment must regain a key role to scaling up capital formation and providing capital goods and investment needed to secure human development objectives like the MDG's.

Further in a critical analysis by Roy et al [8] show that the dogmatic neoliberal policies and the SAP programs have worked against public investment in developing countries. Public capital formation in developing countries reached its peak around 1982, when it came to 10 percent as a share of GDP (both simple and weighted average). At the Millennium shift this figure had dropped to 7 percent (simple average) or 5 percent (weighted average). For sub-Saharan Africa the picture is even grimmer. From a peak in public investments all categories of 15 percent (weighted average) 1978 at the end of the era of basic need strategies it has fell to 5 percent the year 2000. Concerning the share of public infrastructure investments in Africa it has dropped from a little more than 4 percent in the beginning of the 1980 s to 1.5 percent at the Millennium shift. This has forced the World Bank admit that the lack of adequate infrastructure services has direct detrimental effects on the poor's access to clean water and sanitation and thus health [9].

Setting up the MDG's must be seen as some kind of response against this background. They were not a result from the developing countries themselves. They were pushed primarily by the triad [the United States, Europe, and Japan] and were co-sponsored by the World Bank, the IMF and the OECD. The goals were adopted by acclamation by a resolution of the United Nations General Assembly. They were prepared in a consensus process under the governance of the triad, which departed from the UN tradition to carefully prepare important issues in democratic set up committees. According to Amin [10] it was a wellknown consultant for the CIA, who drafted the first version of the millennium goals

The goals are not very radical by themselves. To "reduce extreme poverty and hunger by half" will still keep a second half of millions of poor people with 
extreme poverty and hunger, even if the goals will be obtained. "To reduce by half the proportion of people without sustainable access to drinking water" has an even lower ambition than the International Drinking Water Decade 1981-1990 set up 1977 by the United Nations Water Conference at Mar del Plata. Its aim was to make access to clean drinking water for all available across the world. Moreover, as the goals were processed in a consensus they are so general that everybody can agree upon them, but devoid of any critical analysis of the poverty problem. It is plainly assumed that goals can be achieved by some improved neo-liberalism.

\section{Ghana}

The intention in this section is by using Ghana as a case to illustrate some of the implications and consequences of the global neo-liberal policies. This will be carried through by providing quantitative and quality information on the main natural and infrastructure assets, the social context the resource use is dependent on, especially government policies, and the functioning of the water management system, especially the privatisation process of the Ghana Water Company.

\subsection{Natural resources endowment}

Ghana is situated in the tropical and savannah zones in West Africa. It has a land area of 239460 sq. $\mathrm{km}$, which is about half the area of Sweden. The present population is around 20 million inhabitants, which a little more than double of Sweden.

Rainfall is rather abundant, but irregular and dependant on seasons. The tropical south-western part of Ghana is the wettest and receives 1500 to 1900 $\mathrm{mm}$ of rainfall per year. The driest area is the south east-coastal plain, where mean annual rainfall is less that $750 \mathrm{~mm}$. The savannah area the covers the northern and eastern parts of the country receives between $1000 \mathrm{~mm}$ to 1400 $\mathrm{mm}$ of rain per year.

Some two third of the land area is covered by the lower Volta River system, which basically coincides with the savannah area. Volta river is an international river also including a big part of Burkina Faso, but also smaller parts of Ivory Coast, Mali, Benin and Togo. The water availability in 1995 within the international basin was 2054 cubic meter per person, which is at the limit where water managers consider societies will enter into a phase of difficulties to supply problems. In addition to the Volta river the south-western tropical part have several important regional water basins. In 1990 the water availability for the whole of Ghana was given to 3529 cubic meters per person, which classified Ghana in a rather favourable water resources position. However according to a UN medium projection the water availability will decrease to 1395 cubic meter per person by 2025 , which will convert Ghana into a water-stressed country [11].

Except from valleys plains most Ghanian soils are old, have a rather sandy texture and strongly leached. This means that they have low capacity to retain water and poor in nutrients. Especially in the savannah zone where the organic 
matter is low and where the practice of annual bush-fire is common the soils are deficient in nitrogen and phosphorous [12]. Thus people's livelihood is dependent on a careful and planned agricultural development and land management.

The south-western part and the most forested area of the country is endowed with rich mineral resources including gold, diamond, bauxite and manganese. For instance most gold production is mined by 11 multinational mining companies of which five of them count for 83 percent of the output [13]. There are also a growing number of small scaled local gold producers, mostly illegal, which has led to numerous conflicts with the multinationals.

The most important infrastructural asset and engineering project constructed after Ghana's independence 1957 and the life-nerve of the economy of Ghana is the Volta River dam. Already the Colonial Administration started in 1924 considering a water development project for the Volta River system. For the socialist-orientated first president of Ghana Kwame Nkrumah the Volta River project became the cornerstone for modernization starting a process of increased wealth and prosperity for all. The main engineering component was the Akosombo dam which was completed between 1962 - 1965. The construction was a collaboration between the nationalist government and the Volta Aluminium Company (VALCO), the latter jointly owned by the U.S. Kaiser Company and the Ghanian government. The project was supported by loans from the World Bank/International Bank for Reconstruction and Development (IBRD), the government of Unites States and by export credits guarantees from the United Kingdom government. Even with this loan package support the Nkrumah government had to raise from its own resources 50 percent of cost of the project, and take responsibility for the debt service. A prerequisite for the project was to provide cheap electricity for the VALCO aluminium smelting factory set up in Tema, a new planned harbour town constructed to the east of Accra.

The construction of the dam impounded a huge man-made reservoir, the Volta Lake, which has a surface area of 8500 sq. kilometres and a volume of 148 cubic kilometres. Today the international watershed is poorly forested with less than one percent forest cover. Grassland, savannah and shrubland make up 86 percent and only 0.1 percent is irrigated. A rural population of 80000 people had to be displaced and resettled under difficult conditions. At the start 1965 the Akosombo dam was installed with $588 \mathrm{MW}$ capacity. Later it has been enlarged to $912 \mathrm{MW}$, and smaller dam down-streams at Kpong with a capacity of 160 MW has been built. These two dams in the Volta River system represent 95 percent of the hydropower electricity capacity in Ghana and was the principal source of electricity up to the millennium shift. Since 1999 a couple of thermal plants with a total capacity of $660 \mathrm{MW}$ is under construction at Aboardze near Takoradi in the western part of the country $[14,15]$.

If the neo-liberal policies and SAP programs, applied for more than two decades, have been efficient and equitable one could expect progress in the environmental sustainable use of the natural resources and infrastructure assets. 
But the reality according to Green Dove magazine is that "land management aimed at sustainable agricultural production, exists only in theory. Available statistics indicates that about 69 percent of the total land surface of Ghana is considered prone to severe soil erosion, on of the major causes of land degradation in Ghana. According to government National Action Programme to combat Drought and Desertification, the land area prone to desertification, has almost doubled in last decade. The most vulnerable being the Northern Savannah areas with the Upper East Region being the most degraded. The consequences are low agriculture output and widespread poverty. This has led to the migration of young women and men to the urban centres to seek for jobs with women serving in a demeaning manner as porters (Kayaye) in the markets of Accra. Migration of farmers down south to seek fertile agricultural land is also on increase. The movement is leading to many problems including clashes with other farmers in the south...In addition to the reduction of the agricultural potential, erosion has caused siltation and drying up of water bodies. Most settlements are faced with this menace where buildings have their foundations exposed and hanging, posing threat to people. Occasionally these buildings have collapsed causing damage to life and property" [16]. Most rural households are managing at subsistence level and use mainly manual labour and minimal external inputs. It is estimated that the mineral fertilizer use is only $6 \mathrm{~kg}$ per ha for a wide variation of food crops [12].

As to control of water pollution there exists no workable monitoring system either at the national level or the basin level. In a study of the management of the Densu River basin in the western up-hill Accra region Okyre-Darkoh [17] found no monitoring data at all, and had to rely of people's subjective perception to get some idea of the water quality situation. Lack of a proper monitoring system is crucial factor to consider by the European Union through its EU Water Initiative, which in rather general terms advocate sub-Saharan governments to apply the globally adopted Integrated Water Resources Management (IWRM) system of basin management [18].

In the south-western mining land conflicts and water management is a widespread and a controversial problem. The mining activities give rise to severe water pollution and mining concessions in recent years encroach upon forest reserves. Hilson and Nyame [13] states that " the management of multinational mining corporations operating not only in Ghana, but in the developing world as a whole acquire land concessions expecting the outcome to be problem-free". They see this attitude as unrealistic, because "impoverished informational resources bases, understaffed government departments, piecemeal regulation and ad hoc enforcement persist in most developing countries" including Ghana. Another study by Appiah [19] concludes that the Environmental Protection Agency (EPA) remains ambivalent about the powers vested in them to strictly apply the environmental impact assessment (EIA) regulations. Most mining companies has not undertaken any comprehensive EIA guiding their operations or mitigating measures, while the corporate will and responsibility toward the environment is mediocre or non-existent. It is just two years ago that the Minerals Commission, the EPA and a Swedish consultancy firm (Hifab) have 
started a three years project in the mining areas and funded by the EU Commission, which aims to increase awareness of the necessity of EIA procedures and includes setting up a monitoring system of the rivers.

At the Millennium shift international VALCO company, the mining multinational companies and other industrial consumers made up about two thirds of the total electricity consumption. The commercial sector (offices, shops, institutions and hotels) accounted for $5-6$ percent. Still 50 years after the construction of the Akosombo dam the VRA supplies less than 20 percent of the household energy needs. The rural areas are poorly electrified as the priority has been given to the urban elite to receive electricity for residential needs. A large number of rural households have to rely on biomass sources of energy such like fuel wood for the cooking need, which as a consequence have increased the land degradation and erosion problems. Very little compensatory measures have been taken to assist the affected communities and for them to benefit of the electricity generation by the Volta River Project. Wide-spread deforestation, erosion and the incidence of environmental health problems, particularly bilharzia, have been recognized as the most acute environmental problems within the surrounding communities of the Volta dams and lake [14,20].

The environmental health and pollution situation in the urban and peri-urban areas of Ghana is in a dilapidated situation. The Ghana Water Sector Restructuring Secretariat (WSRS) found in the beginnings of century that 53 percent of the population, but 78 percent of the poor, had no piped water. A study in 2001 found that that only 40 per cent of the urban population had access to piped water supplied by the Ghana Water Company. Some 40 percent in urban areas and 35 percent in the rural areas had access to improved sanitation facilities [21]. Only the central and old urban areas have a water supply network, which mostly reaches the wealthiest residents [22]. Tema, the city built out as a planned effort as a part of the Volta River project, has modern sewerage facilities, however discharging the sewage water untreated in the Atlantic. After advice from the World Bank the Rawlings government in 1998 separated the water supply from sewage disposal in a process called "unbundling". Water supply was left with the renamed state owned company Ghana Water Company Ltd, while the sewage disposal was devolved to the district level. These districts either have enough human resources capacity or financial resources to take care of this responsibility. Although some small technological efforts since the middle of the 1960s have been made, there exist no workable sewage treatment plant at all in the country. A biological filter sewage plant at the University of Ghana, built in the 1980s, quickly went out of operation due to lack of spare parts, and is now partly overgrown with vegetation.

Thus the state of environmental health, water supply, sanitation and waste management in Accra is currently very unsatisfactory [23]. Several times a week the press carries articles which complain of the situation [24]. The bulk of the sewage water in the city, both domestic and industrial, continues to be discharged into gutters and drains most of which empty into the Korle Lagoon in the centre of the city. In addition night soils and septic tank sludge are deposited by tanker trucks directly on the beaches. The city then gives a filthy impression, 
since it is characterised by choked drains, indiscriminate waste disposal and uncollected refuse in central waste containers. The Waste Management Department of the Accra Metropolitan Assembly is responsible for garbage collection and disposal, and general sanitation situation within Accra, but it is not capable to improve the present conditions.

Many factors contributes to this state of affairs like; the collapse of a comprehensive planning system for the urban areas, poor conceptualisation of environmental health, sanitation and water management issues, lack of adequate treatment facilities, ignorance and irresponsibility of individuals, households, communities and administrations, lack of community action, spring up unauthorised temporary structures, continuously increasing number of squatters, lack of regular budgetary allocations, absence of governmental control etc. In sum the market-orientated neo-liberal policies applied by the Rawlings and Kufour governments have not contributed to the progress of environmental sustainability.

\subsection{The social context - government policies}

The neglect of creating environmental sustainability is due to that the Ghanian governments within the global context favours economic and fiscal sustainability. However, this has not lead to a substantial economic growth in the per capita income. The GDP per capita stood at $\$ 390$ at the Millennium shift, which is just at the level of the Nkrumah government $1957-1966$. The per capita income was at its lowest value 1983, when it was only 90 percent of the 1957 value. In 1983 the Rawlings government started the Economic Recovery Program and SAP programs under the auspices of the Bretton Wood Institutions. Thus, the recovery relying on market reforms has been slow and has been accompanied by a sharpened and skewed income distribution, regional disparities and social exclusion [25-27].

The subservience to the global economic forces is elegantly formulated in the introduction to the Ghana Vision 2020 plan, which was introduced by the Rawlings government in 1995.

"The long-term vision for Ghana is that by the year 2020, Ghana will have achieved a balanced economy and a middle class country status and have a standard of living with a level of development close to the present level of Singapore. This will be realized by creating an open and liberal market economy, founded on competition, initiative and creativity, that employs science and technology in deriving maximum productivity from the use of all our human and natural resources and in optimizing the role of economic and social development, with due regard to the protection of the environment and to equity in the distribution of development" [28].

This lofty vision void of a political analysis has been accompanied by an Interim Poverty Reduction Strategy Paper 2000 - 2002, and a Ghana Poverty Reduction Strategy Paper (GPRS) 2003 - 2006. The IMF and the World Bank 
endorsed in 1999 the elaboration of Poverty Reduction Strategy Papers (PSRPs) as the central mechanism to for providing concessional lending to low-income countries. The declared objective of these papers is to provide a medium-term framework to reduce poverty and generate more rapid economic growth with assistance from bilateral donors and multilateral financial institutions. The PSRPs contains rather general commitments to improve the social infrastructure like environmental health, water supply and sanitation, and it is assumed that funding for investments should be raised besides from donors and financial institutions through governments own revenues, eventual savings from getting the status of Highly Indebted Poor Country (HIPC) debt relief and private sector contribution either by the business or the NGOs. This fits well with the MDG No 8 to "develop Global Partnerships for development" and Private-SectorParticipation (PSP) approach to achieve global and local consensus developments, endorsed at the Johannesburg 10+ meeting 2002.

Unchecked neo-liberal policies and the weak economy of the Ghana state keep the country within the global corporate agenda in a stage to produce staple commodities for the world market, particularly agricultural and mineral products. The Ghana Vision 2020 puts agricultural production in focus. However the agricultural sector is quite vulnerable and skewed. Some 70 percent of the population gets its livelihood directly or indirectly from the agriculture sector. It is estimated that small-holder farmers, who use mainly labour and minimal external inputs, contributes to about 80 percent of the total agricultural production. During the period 1996 - 2002 the agricultural sector contribution to GDP (in constant 1993 prices) has been within 39.5 to 40.8 percent, the service sector 31.3 to 33.0 percent and the industrial manufacturing sector 27.4 to 28.0. The agricultural sector contributed with $\$ 732$ million in 2002, which is equivalent to an average of 35.0 percent share of the total foreign revenue for the 2000-2002 period. This is a decrease from an average of 44.8 percent during the 1996-1998 period, which could be explained by a rapid increase in the minerals production during the ends of 1990s. The main agricultural export commodities in 2002 were cocoa $(\$ 463)$, timber (\$183) and pineapple (\$15). Especially worrying for a lot of small-scaled cocoa producers are that the export earning share of cocoa fell from 35.1 percent in 1996 to 22.4 percent in 2002. As a basis for the government development efforts the agricultural sector just contribute a meagre 4 percent to the total government revenue in the first years after the Millennium shift [12,29].

In addition with the global trade liberalisation Ghanian farmers have been compelled to compete against cheap imports of highly subsidised products from the European Union and the United States like rice, chicken, tomatoes etc. For instance cheap rice imports from United States is not only collapsing the local rice industry, but also beginning to have a substitution effect on locally produced staple foods like cassava and maize. Adjei-Nsiah [12] writes that this is compounded by "increasing cost of inputs at the farm level due to SAP programs that have removed subsidies and increased supply cost due to the deterioration conditions of rural infrastructure. For instance, in 2002, whereas metric tonnes of urea cost about $\$ 90$ free on board in Europe the same quantity cost a Ghanian 
farmer about \$ 308 at the farm level". What is left for the Ghanian politicians is to become flagbearer advocating mechanization of food production, but in an ideological an organizational vacuum [30].

In the early 1990s gold overtook cocoa as Ghana's chief foreign exchange earner. As for this staple export sector the mining companies during the SAP intensive period 1990 - 2002 paid $\$ 69$ million in royalties and \$19 million in corporate tax to the government according to the Bank of Ghana. This becomes on average some $\$ 7$ million per year, a figure of less then 50 percent of the pineapple industry export earnings in 2002. By law 80 percent these payments goes to the government, 10 percent to the mining agencies and the remaining 10 percent to the Office of the Administrator of Stool Lands. Of this last share 10 percent is kept for the Stool Lands administration leaving the rest or $\$ 0.61$ million for community developments to district assemblies, traditional authorities and stools of the mining areas. This extreme exploitation of a lowincome country should be compared with that the mining industry is estimated to have invested \$ 250 million per year between 1983 - 1998 [13].

It should be obvious for everyone that's this basically un-regulated and unplanned market economy to produce staple commodities for the global capitalistic market will not contribute to social equity, overall wealth building and thus poverty reduction. Development in general terms means in a planned way to modernize the agricultural sector, so that labour not any longer needed in agriculture in an orderly way will be transferred to growing manufacturing and service sectors. This is not the case in Ghana and most other low-income countries.

Sutcliff [31] wrote; " no major country has yet become rich without having become industrialized...In the long run greater wealth and better living standards under any political system are connected with industrialization". After two decades of SAP programs and liberalized global markets the manufacturing industry in Ghana today is in distress. The country is supposed to continue the road of liberalization and hopefully improve the competitiveness of its manufacturing firms in the long run without completely destroying the manufacturing base in the short run [32]. This is an equation impossible to achieve.

On the contrary, since the demise of the basic needs and planned development approach at the end of the 1970s an alarming unplanned rural exodus have taken place, which sharps regional disparities and creating huge infrastructure, environmental and social development problems in quickly growing urban and peri-urban areas. Large number of people has been driven into a petty commodity sector, surviving through a great diversity of copying strategies outside of the main national economy [33].

The applied neo-liberal anti-development policies make the Ghanaian state very weak. The official budget policy of the sitting Kofuor government, elaborated in collaboration with the IMF, is "to sustain the fundamental underpinnings of a stable and durable economy" and the implementation of prudent fiscal and monetary measures by the government since 2001." [34]. In this policy is an inherent contradiction between the need to undertake growth- 
enhancing expansion in expenditure and the demand for further fiscal restraint as a disinflation policy. Currently the government strives to achieve single digit inflation.

In 2005 the GDP reached 97018 billion cedis or $\$ 10.800$ billion. In the same year the government total revenue and grants (including HICP Assistance) stood at 28800 billion cedis $(29,7 \%$ of GDP), while the current and capital expenditures came at 32078 billion cedis (33.1\% of GDP), leaving a budget deficit of some 4 percent of GDP. This is substantially lower than the $7-10.5$ percent during the $1993-2000$ period. Under this budget circumstances only 4.8 percent was left for domestic public capital formation investments, and only 2.8 of GDP in the form of social security, pensions and health insurance benefits to households. In addition the government wage bill was almost 50 percent of the recurrent expenditures or 9.4 percent of the GDP $[35,36]$, which gives little room for the government to expand public human resources capacity building needed for sustainable development.

\subsection{The water management system}

A weak state makes public planning and management efforts difficult, and the water sector is no exception. The current reformation of the water sector was initiated in the end of 1990s as a part of Ghana poverty reduction strategy. The reformation of the sector aims to obtain a society where the whole population has access to basic social services such as health care, drinking water and sanitation. It includes the creation of a new sector policy, re-management of the sector agencies and administration, delegation of responsibilities to districts and communities and a higher degree of involvement of the private sector.

With limited state capacity and the dependency of external finance and conditionalities it is not any easy task to restructure the multitude of water institutions. The Ministry of Works and Housing (MWH) is in charge of creation of policies in the water sector and the coordination between them, but the Ministries of Environment and Science, Health and Local Government and Rural Development are also involved. The Water Resources Commission (WRC) is the main institution to involved in regulation and management of the water bodies in Ghana related to the Integrated Water Resources Management approach advocated by the global financial and water institutions. Other important institutions are the Environmental Protection Agency that should regulate and enforce environmental quality laws and the Water Research Institute that is mandated to conduct research into water and water related research [37].

For the achievement of the MDG's the organization of the water utility sector is of special interests to illustrate the close IFIs and international private sector influence on Ghanian public policies. The initial restructuring work was first carried out in working groups inside MWH, but in 1997 a Water Sector Restructuring Secretariat (WSRS) was set up in the ministry. It received the mission to supervise the transition from existing Ghana Water and Sewage Company (GWSC) structure to a Private-Sector-Participation (PSP) regime. The World Bank funded it and it advises the government on PSP issues [38]. 
The WSRS claimed that efforts in the 1970s and 1980s to restructure GWSC and improve its operational and financial viability had failed. Therefore in a WSRS workshop in February 1995 without any trade union representation, but with numerous participation of international aid donors and global private water companies, eight PSP options were discussed and the lease option was selected. The same year, on World Bank advice, came a proposal to restructure the GWSC into a pure and profitable water supply company. This restructure materialized in 1999, when the Ghana Water Company (GWC) was set up getting the authority to supply 101 urban systems with water. At the same time the water supply systems in 110 rural communities and small towns were devolved to District Assemblies at the local government level. Also all sewerage and sanitation handling over the whole of Ghana became the responsibility of the District Assemblies. Further in 1997 a Public Utility Regulatory Commission (PURC) was established. Its main task was to set the water rate for consumers after a proposal from the utility. The IMF asked PURC to implement a plan for full cost recovery and an automatic tariff adjustment mechanism as a condition for Poverty Reduction and Growth Facility loans. In the Interim Poverty Reduction Strategy Paper 2000 - 2002, in theory a borrowing document, but in practice written by the lending organisation, the urban water sector was scheduled to "divest urban water systems to private sector operators: issues invitation for bids". During the whole process a number of biased western consultants were hired like Louis Berger, London Economics, Halcrow \& Halcrow, WS Atkins, Stone and Webster, The Adam Smith Institute. After all this efforts the bidding process was elaborated [21].

The first pre-qualification bid process was launched in 1998, and the two largest global water companies Suez and Vivendi/Veolia were selected for a lease contract. The whole process lacked transparency from the beginning, so eventually a third company, Azurix, was accepted without being officially invited. It went around the Negotiation Office to address directly with the Rawlings government [39]. Azurix was the water division of the later scandalised U.S. energy company Enron. In 2000 the MWH made a decision to award Enron/Azurix the lease contract, but after allegations of kick-backs and media coverage, even the World Bank threatened to abolish some of its concessionary loans unless the Government of Ghana cancelled the awarded contract.

The Enron/Azurix debacle increased the general awareness among a wide range of civil society organisations and the public of what was planned for the water and sanitation issues in Ghana. In May 2001 a National Forum on Water Privatisation was arranged in Accra. The Forum adopted "The Accra Declaration of the Right to Water", a document that is widely spread in the international community [40]. It states "that water is a fundamental human right" and "that water should not be a common commodity to be bought and sold in the market place as an economic good". It also rejected "the view that privatization (the participation of foreign transnational corporations) is the appropriate solution to the problems bedeviling our water sector". At the Forum the National Coalition Against the Privatisation of Water (NCAP) was formed and its secretariat set up 
in the Trade Union Congress (TUC) premise. The NCAP has since than campaigned for keeping the water supply in public hands.

Before the second bid process the Ghana urban water system was divided in two project units $\mathrm{A}$ and $\mathrm{B}$ with about equal capacity, each of them expected to be operated by a foreign company. The rationale for this was that two contract should secure competition. After the pre-qualification process the French companies Suez, Vivendi and SAUR were selected together with Biwater, a British company. Due to increased national and international debate of the privatisation issue the selection procedure was delayed and the government hesitated to take a decision [41]. Finally the government and the WSRS made a retreat and changed the bidding requirements from long-term lease contract into a five years management contract.

On 22 November 2005, the Ghana government [grantor] officially signed a Management Service Contract agreement with two international public-owned companies, Vitens International B.V of the Netherlands and Rand Water Service Pty, of South Africa [42]. These two company set up a joint 50-50 owned special purpose company, Aqua Vitens Rand Ltd (AVRL), which started its activities 1 July 2006. According to this arrangement GWC should monitor the performance of the contract and PURC negotiate the water rate. AVRL obligations under the contract include increasing the amount of treated water for sale, extending water service to low income areas, rehabilitating existing networks to reduce nonrevenue water, dam safety upgrades, procurement and installation of meters etc. within a five year period. For AVRL to accomplish this mission the government of Ghana was granted a loan of \$103 million from the World Bank, \$5 million from the Nordic Development Fund and an equity contribution of \$12 million. The regional staff of the GWC has been transferred to the AVRL in a retrenchment process that at the end will reduce 4700 former GWC staff to a few more than 1 500. The GWC Head Office is in a similar retrenchment process to slim its staff from 240 to some 60 people [43].

At the signing of the contract the civil society groups criticized the management contract and challenged the government to provide Ghanians with evidence of anywhere in the world where a management contract had been able to deliver water at an affordable rate to the poor [44]. According to the agreement AVRL is obliged to within six months of the commencement date of the contract to "produce and maintain water quality, pressure and flow rates at all discharge points". After a bit more than half a year staff at the GWC Head Office accuse AVRL for ripping of GWC and the government, because not even a single pipeline or meter have been added to the company 's old stock, and that it had not introduced anything new to improve the performance of the GWC. AVRL is also criticized for the World Bank sponsored retrenchment process, and the government for paying eight AVRL managers \$20000 per month to replace Ghanians managers $[45,46]$.

It should be obvious for everyone that in the PSP process of Ghana Water company it is impossible to distinguish between government and World Bank policies. 


\section{Concluding remarks}

It has been demonstrated in this paper with Ghana as a case that global corporations and the International Finance Institutions, particularly the World Bank and the IMF, have the privilege to define what is environmental sustainability and accordingly interpret the MDG No 7 phrase "integrate the principle of sustainable development in country policies and programmes" at their own will. These global actors always prioritise economic and fiscal sustainability before environmental sustainability.

It should now have become common knowledge that SAP programs have focused on securing macro-economic stability and fiscal solvency by placing controls of fiscal deficits and public debts. The global powers have assigned the low-income countries to deliver staple commodities for the world market. This market-orientated policy has led to increasing inequalities, widening regional disparities, migration from rural areas to quickly grown up peri-urban areas basically within a huge informal sector, and unplanned capital formation and development at large, making claims to half the poverty by 2015 illusory. The implementation of the Bretton Wood institutions SAP programs has not left the governments of low-income countries like Ghana with much choice either than to increase the revenues or to restrain expenditures. Existing national power structure, the large informal economy, and low incomes of middle-class and poor people make increasing tax rates difficult. Thus most low-income governments have been forced to restrict public expenditures, leaving just a few percent of the GDP for domestic capital formation.

The global corporate agenda is covered in rhetoric's from the Rio summit like "Think global -Act Local". However, this is a dangerous message, as it conceals the process of delegitimating national states and governments. With the experience from Ghana Boafo-Arthur [25] expresses this process as; "It is indisputable that the Washington Consensus and neo-liberal adherents just want to see the state making laws for the operation of the market but not participating in the market itself...The increasing distancing of the state from direct economic management, as underlined by the extra attention paid to private sector development, is bound to impact negatively on the vulnerable in the society". It is an intriguing fact that this rhetoric has made North governments, like in the Swedish Global Development Policy 2003, to bypass national governments and focus the international aid on community development. Or stated by the words of the Swedish state secretary of international aid [47] at a meeting to discuss the UNDP Development Report 2006; "People's are the base for priorities, not governments". This statement is also an example of an accompanied shift from "government" to "governance" with the implication that state power has moved from democratic governments upwards to organisation like the European Union or to local network-type power centres or PSP arrangements. At local level this implies that private actors like companies and NGOs not only participate in developing policies, but also in many cases perform in implementing political decisions, for instance in the delivery of service [48]. Sometimes this shift creates confusion as when the General Director of Sida on the one hand 
expressed that the above Swedish Global Development Policy "has the special goal to contribute to an environment that support people's own initiative" and on the other hand when problems occur at the local level to implement the MDG's stated that "Governments need to take responsibilities, that is what we have governments for" [49].

The Rio summit occurred in time together with the Gulf War of 1991 and the demise of the Soviet Union, which gave rise to rhetoric's of a "new world order" and even "the end of history". Ten years later at the Johannesburg 10+ the reality had given away to disappointment. As Bellamy Foster [50] writes "rather than improving of the decade that had elapsed, the word environment had experienced accelerated decline...Sustainable development had turned out to be about sustaining capital accumulation at virtually any ecological cost. All rhetoric ten years earlier of a 'new world order' and 'the end of history' had simply disguised the fact that the real nemesis of the global environment was the capitalist world economy".

Western-styled neo-liberal policies and governance receipts will never get the sub-Saharan countries out of the poverty trap and the environmental abuses. Ghana celebrates its 50 anniversary of independence this year. The country can learn from the planned national development efforts of the Kwame Nkrumah's first independent government [51]. The way forward for Ghana should also be to gradually fence off from the global world market and build an environmental sustainable modern society based on regional co-operation and developing its own internal markets.

\section{Acknowledgement}

The work with this paper has been supported by a grant from the Formas-Sida research councils, Sweden.

\section{References}

[1] Poverty-Environment Partnership, Linking Poverty Reduction and Water Management, SEI \& UNDP publication, Stockholm: 2006.

[2] Kuttner, R., Everything for Sale, The University of Chicago Press: Chicago, 1999.

[3] Schmidheiny, S., Changing Course: A Global Business Perspective on Development and the Environment, MIT Press: Cambridge, 1992.

[4] Giddings, B., Hopwood. B. \& O’Brien, G., Environment, economy and society: Fitting them together into sustainable development. Proc. Of the Int. Conf. on International sustainable development research, University of Manchester: Manchester, pp. 79-86, 2001

[5] Stedman L., Water: the development deficit. Water21, December 2006.

[6] Report for the Commission of Africa, Our Common Interest: London, 2006.

[7] IMF, Public Investments and Fiscal Policy: Washington D.C., 2004. 
[8] Roy, R., Heuty A., \& Letouzé, E., Fiscal Space for Public Investment: Towards a Human Development Approach: Paper prepared for the G-24 technical meeting Singapore, September 13-14, 2006, UNDP.

[9] Development Committee, Infrastructure and the World Bank, World Bank: Washington D.C. 2005.

[10] Amin. S., The Millennium Development Goals. A Critique from the South, Monthly Review, 57(10), 2006, pp 1-15, 2006

[11] Engelman, R. \& LeRoy. P., Sustaining Water - Population and the Future of Renewable Water Supplies. Population and Environment Program: Washington, 1993.

[12] Adjei-Nisah, Cropping system, land tenure and social diversity in Wenchi, Ghana: implications for soil fertility. $\mathrm{PhD}$ thesis, Wageningen University: The Netherlands, 2006

[13] Hilson, G. \& Nyame, F., Gold mining in Ghana's forest reserves: a report on the current debate. Area, 38 (2), pp. 175-185, 2006.

[14] Agbemabiese, L. \& Byrne, J., Commodification of Ghana's Volta River: An Example of Ellul's Autonomy of Technique. Bulletin of Science, Technology and Society, 5(1), pp. 17-25, 2005.

[15] Volta River Authority (VRA), www.vra.com

[16] Editorial, Land, Degradation and Agricultural Development. Green Dove, No 37 August, 2006.

[17] Okyere-Darkoh. B., Land Use Problems and Prospects of River Basin Management in Ghana: The Case of Densu River, MSc Report No 31, Department of Land and Water Resources Engineering, KTH: Stockholm, 2001.

[18] Aziz, A., Organizations concerned about pollution of River Densu. Daily Graphic. 16 October, 2006.

[19] Appiah, D. V., Environmental Impact Assessment Regulations: The Level of Compliance by Mining Companies in the Western Mining Enclave, Ghana. TRITA-LWR Master Thesis, No 11, KTH: Stockholm, 2006.

[20] Girmay, Y., Assessing the Environmental Impacts of a Hydropower Project: The case of Akosomo/Kpong Dams in Ghana. TRITA-LWR Master Thesis, No 04, KTH: Stockholm, 2006.

[21] Report on the International Fact-finding Mission on Water Sector Reform in Ghana, ISODEC: Accra, 2002.

[22] Akuffo, S.B., Pollution Control in a Developing Economy: A Study of the Situation in Ghana. Ghana University Press: Accra 1998.

[23] Songsore, J., Nabila, J.S., Yangyouro, Y., Amuah, E., Bosque-Hamilton, E.K., Etsibah K.K., Gustafsson, J-E., \& Jacks, G., State of the Environmental Health: Report of the Greater Accra Metropolitan Area 2001, Ghana University Press: Accra, 2005.

[24] E.g. Yankson, N., Sanitation plight at Nima worsens. The Chronicle, 11 October, 2006; Yeboah A.L., Celebrating in filth? Daily Graphic, 2 November, 2006. 
[25] Boafo-Arthur K. A., A decade of liberalism in perspective (Chapter 1). Ghana - One Decade of the Liberal State, ed. K.A. Boafo-Arthur, Zed Books: London, 2007.

[26] Songsore, J., Regional Development in Ghana: The Theory and The Reality, Woeli Publishing, Ghana, 2003.

[27] Leith, J.C. \& Söderling, L., Ghana - Long Term Growth, Atrophy and Stunted Recovery, Nordiska Afrikainstitutet: Research report no.125, 2003.

[28] Government of Ghana, Ghana Vision 2020: The First Medium-Term Development Plan, National Planning Commission: Accra, 1997.

[29] The State of the Ghanian Economy 2002. ISSER: University of Ghana, 2003.

[30] Asamoa, A., Depeasantization of Africa's Rural Economy: The Ghanaian Case. Charities Aid Foundation: Accra, 2001.

[31] Sutcliff, R.B., Industry and Underdevelopment, Addison and Wesley: London 2001.

[32] Yankson, P.W.K., Urbanization Industrialization and National Development: Challenges and Prospects of Economic Reform and Globalization, Ghana University Press: Accra, 2006.

[33] Songsore, J., Towards a Better Understanding of Urban Change. Urbanization, National Development and Inequality in Ghana, Ghana University Press: Accra, 2003.

[34] 2006 Budget Statement, Overview of Economic Policy and the Budget for 2006. The Ghanaian Times, 12 November 2005.

[35] Review and Analysis of Government Economic Policy 2006, CEPA: Issue Paper, No 12, Accra, 2006.

[36] Executive Summary Ghana Economic Review and Outlook, CEPA: Accra, 2006.

[37] Lundgren, A \& Åkerberg, H., Rainwater harvesting in the peri-urban areas of Accra: status and prospects, TRITA-LWR Master Thesis, No 13, KTH: Stockholm, 2006.

[38] Water Sector Restructuring in Ghana. The Decision, The Framework, The Issues, WSRS, Ministry of Works and Housing: Accra, 2003.

[39] Nkrumah, E. Personal communication, 2 December 2003, WSPR, Accra.

[40] www.isodec.org.gh/Papers/accradeclaration.PDF

[41] Ford, N., Crunch time over privatisation. African Business, March 2004.

[42] WSRS, www.waterforghana.org

[43] Korsah, E. Personal communication, 31 October, 2006, GWCL, Accra.

[44] Nyarkoah, M., Hackman's water theory is bogus. Why are they lying to us? The Chronicle, 25 November, 2005.

[45] Adabre, J. \& Amankwah, A. A., Uneasy Calm at Ghana Water Company. Public Agenda, 22 January, 2007.

[46] Nortey. L, Pay Water Workers Well -NCAP. Accra Daily Mail, 17 February, 2007. 
[47] Stymne J., Quotation, Swedish Water House Meeting; Water, Power and Poverty- How Clean Water and Sanitation Will Cut Poverty in Half by 2015. 2 February, 2007, Stockholm.

[48] Vifell, Å., Enklaver i staten: Internationalisering, demokrati och svensk statsförvaltning. Stockholm Studies in Politics 113: Sthlm University, 2006.

[49] Norrfalk M., Quotation, Swedish Water House Meeting; Water, Power and Poverty- How Clean Water and Sanitation Will Cut Poverty in Half by 2015. 2 February, 2007, Stockholm.

[50] Bellamy Foster, J., The Ecology of Destruction. Monthly Review, 58(9), pp. 1-14, 2007.

[51] Nkrumah's legacy, 25 pages of tributes on the African of the 20th century. New African, February 2006. 